\title{
REVIEW BENTUK INTEGRASI ISLAM DALAM PENDIDIKAN IPA DI INDONESIA
}

\author{
Noor Fanika ${ }^{1}$, Riza Umami ${ }^{2}$, Muhamad Imaduddin ${ }^{3}$ \\ Institut Agama Islam Negeri Kudus \\ noorfanika2@gmail.com
}

\begin{abstract}
Research aims to determine the form of application of Islamic integration in science education in Indonesia. The method in this research uses a systematic review meta-analysis method. The data used in the study were obtained by collecting journals using the Sinta journal index 1 to 6. This time the writer used qualitative techniques and used the prism method. The results showed that in the journals Sinta 1 to Sinta 6 there were 193 journals found in the search for keywords on science and science education. From 193 journals, it was found that there were 47 articles related to Islam and 10 articles related to the Al-Qur'an. It is concluded that the application of Islamic integration in science education has been carried out quite a lot and has various forms of application of Islamic integration. Researchers found various topics related to Islamic integration. However, the integration of Islam in the form of science learning in Indonesia is still small because the number of resources with a background in humanities and social sciences is more dominant. The development of Islamic values in education can be done through the development model of teaching materials, methods, or learning approaches.
\end{abstract}

Keywords: Forms of Islamic Integration, Science Education

\begin{abstract}
Abstrak : Penelitian bertujuan untuk mengetahui bentuk penerapan integrasi islam dalam pendidikan IPA di Indonesia. Metode pada penelitian kali ini menggunakan metode metaanalisis sistematikal review. Data yang digunakan dalam penelitian diperoleh dengan cara mengumpulkan jurnal menggunakan indeks jurnal Sinta 1 sampai 6. Kali ini penulis menggunakan teknik kualitatif dan menggunakan metode prisma. Dari hasil penelitian menunjukkan bahwa dalam jurnal Sinta 1 sampai Sinta 6 terdapat 193 jurnal yang ditemukan dalam pencarian kata kunci pendidikan IPA dan science. Dari 193 jurnal ditemukan jumlah artikel yang berkaitan dengan agama islam sebanyak 47 artikel dan artikel yang berkaitan dengan Al-Qur'an sebanyak 10 artikel. Disimpulkan bahwa penerapan integrasi islam dalam pendidikan IPA telah terlaksana dengan cukup banyak dan memiliki berbagai macam bentuk penerapan integrasi Islam. Peneliti menemukan berbagai topik yang berkaitan dengan integrasi islam. Namun, integrasi Islam dalam bentuk pembelajaran IPA di Indonesia masih sedikit dikarenakan jumlah sumber daya yang berlatar belakang sains humaniora dan sosial lebih dominan. Pengembangan nilai Islam dalam pendidikan dapat dilakukan melalui model pengembangan bahan ajar, metode, ataupun pendekatan pembelajaran.
\end{abstract}

Kata Kunci : Bentuk Integrasi Islam, Pendidikan IPA

Islamika : Jurnal Keislaman dan Ilmu Pendidikan

Volume 3, Nomor 1, Januari 2021; 57-67

https:// ejournal.stitpn.ac.id/index.php/islamika 


\section{PENDAHULUAN}

Pada Undang-Undang No. 20, Tahun 2003. Pasal 3 menyebutkan, "Pendidikan nasional berfungsi mengembangkan kemampuan dan membentuk watak serta peradaban bangsa yang bermartabat dalam rangka mencerdaskan kehidupan bangsa, bertujuan untuk berkembangnya potensi peserta didik agar menjadi manusia yang beriman dan bertakwa kepada Tuhan Yang Maha Esa, berakhlak mulia, sehat, berilmu, cakap, kreatif, mandiri, dan menjadi warga negara yang demokratis serta bertanggung jawab." Pendidikan saat ini merupakan suatu kebutuhan setiap orang.(UU RI No. 20 Tahun 2003) Akan tetapi jika hanya mengandalkan pendidikan tanpa adanya peran agama yang mengiringinya maka akan percuma.

Integrasi nilai dalam pembelajaran/pendidikan merupakan proses bimbingan melalui suri tauladan guru yang berorientasi pada penanaman nilai-nilai kehidupan yang di dalamnya mencakup nilai-nilai agama, budaya, etika dan estetika menuju pembentukan peserta didik yang memiliki kecerdasan spiritual-keagamaan, pengendalian diri, kepribadian yang utuh, berakhlak mulia, serta keterampilan yang diperlukan dirinya, termasuk masyarakat dan negara.(Sumantri, E. 2007) Pendidikan IPA di sekolah diharapkan dapat menjadi wahana bagi peserta didik untuk mempelajari diri sendiri dan alam sekitar, prospek pengembangan lebih lanjut dalam menerapkannya di dalam kehidupan sehari-hari, serta lebih menghayati akan keagungan ciptaan Allah swt.

Dalam kita suci al-Qur'an banyak kandungan ayat yang terkait dengan Ilmu Pengetahuan Alam. Telah diperinci dalam sejumlah ayat tersebut yakni :

1. Adanya makhluk hidup di angkasa luar, diterangkan dalam surat al-Isra' ayat 155 .

2. Gelombang-gelombang rupa dan suara dapat direkam dan diabadikan telah dijelaskan dalam surat Zalzalah ayat 6-8.

3. Proses kejadian manusia terdapat dalam surat al-Mu'minun ayat 12-14

4. Proses kejadian alam terdapat dalam surat Fushshilat ayat 9-11.

5. Teori demokritus yang dinyatakan atom benda terkecil yang tidak dapat dipecah, dibantah oleh al-Qur'an bahwa masih ada yang lebih kecil dari 
atom atau atom masih dapat dipecah. Hal tersebut diisyaratkan dalam surat Yunus ayat 61.

6. Sidik jari manusia tidak sama, diisyaratkan dalam surat al-Qiyamah ayat 4.(Departemen Agama RI 1996)

Mengenai bentuk yang digunakan untuk integrasi islam dalam pendidikan IPA bisa bermacam - macam seperti menggunakan bahan ajar modul, LKS, pembelajaran umum dan masih banyak lagi. Untuk itu dalam penelitian ini penulis akan mereview bentuk integrasi islam dalam pendidikan IPA khususnya di Indonesia. Dengan mengambil sampel dari jurnal meggunakan indeks jurnal Sinta 1 sampai dengan Sinta 6. Sampel tersebut akan di pembahasan dengan menggunakan metode prisma.

Sehubungan dengan permasalahan diatas, penulis tertarik untuk melakukan penelitian mengenai "Review Bentuk Integrasi Islam dalam Pendidikan IPA di Indonesia”. Berdasarkan latar belakang yang telah dijelaskan, penelitian ini bertujuan untuk mengetahui berbagai bentuk penerapan integrasi islam dalam pendidikan IPA di Indonesia.

\section{METODE PENELITIAN}

Metode pada penelitian kali ini menggunakan metode meta-analisis sistematikal review. Data yang digunakan dalam penelitian diperoleh dengan cara mengumpulkan jurnal menggunakan indeks jurnal Sinta 1 sampai 6. Meta-analisis adalah salah satu cara untuk melakukan sintesa hasil secara statistik (teknik kuantitatif) dan / atau naratif (teknik kualitatif). Kali ini penulis menggunakan teknik kualitatif dan menggunakan metode prisma.

Tinjauan pustaka yang sistematis dan terstruktur digunakan untuk menganalisis, memeriksa dan mendiskripsikan studi empiris untuk mengkonfirmasi review proses sistematis tersebut, kami melakukan pemilihan item untuk tinjauan sistematis dan pernyataan MetaAnalysis (PRISMA).(Moher, D., Liberati, A., Tetzlaff, J., \& Altman, D. G. 2009) Memiliki langkah sebagai berikut : menunjukan langkah- 
langkah PRISMA dalam meninjau artikel bentuk integrasi islam dalam pendidikan IPA di Indonesia.

Dalam proses pencarian, peneliti mengadakan penelitian terhadap beberapa artikel yang diterbitkan dalam jurnal ilmiah dibidang sains pendidikan dan diindeks oleh lembaga yang dapat dipercaya untuk mendapatkan data bentuk integrasi Islam untuk menganalisis pencocokan studi, peneliti melakukan pencarian di lembaga pengindeksan yaitu Sinta 1, Sinta 2, Sinta 3, Sinta 4, Sinta 5, dan Sinta 6. Diperoleh dari pencarian terdapat 20 artikel jurnal yang didapatkan dengan kata kunci Islam dan alquran.

Kata kunci yang digunakan untuk memperoleh artikel terkait seperti : (1) pendidikan IPA dan science, (2) kata kunci islam dan alquran, (3) lihat bentuk integrasi islam. Proses review dilakukan secara bertahap. Artikel dipilih berdasarkan hasil kata kunci yang dimasukkan dalam pencarian jurnal hasil pencarian akan dibandingkan bentuk integrasi islam dalam pendidikan IPA di Indonesia.

Setelah semua data disajikan kemudian peneliti menganalisis data sesuai pokok permasalahan yang dirumuskan dalam penelitian ini. Dalam menganalisis data, peneliti menggunakan analisis deskriptif kualitatif yaitu mendeskripsikan keadaan yang sesungguhnya dalam bentuk uraian dalam kalimat dengan mengambil metode induktif dalam menarik kesimpulan. 


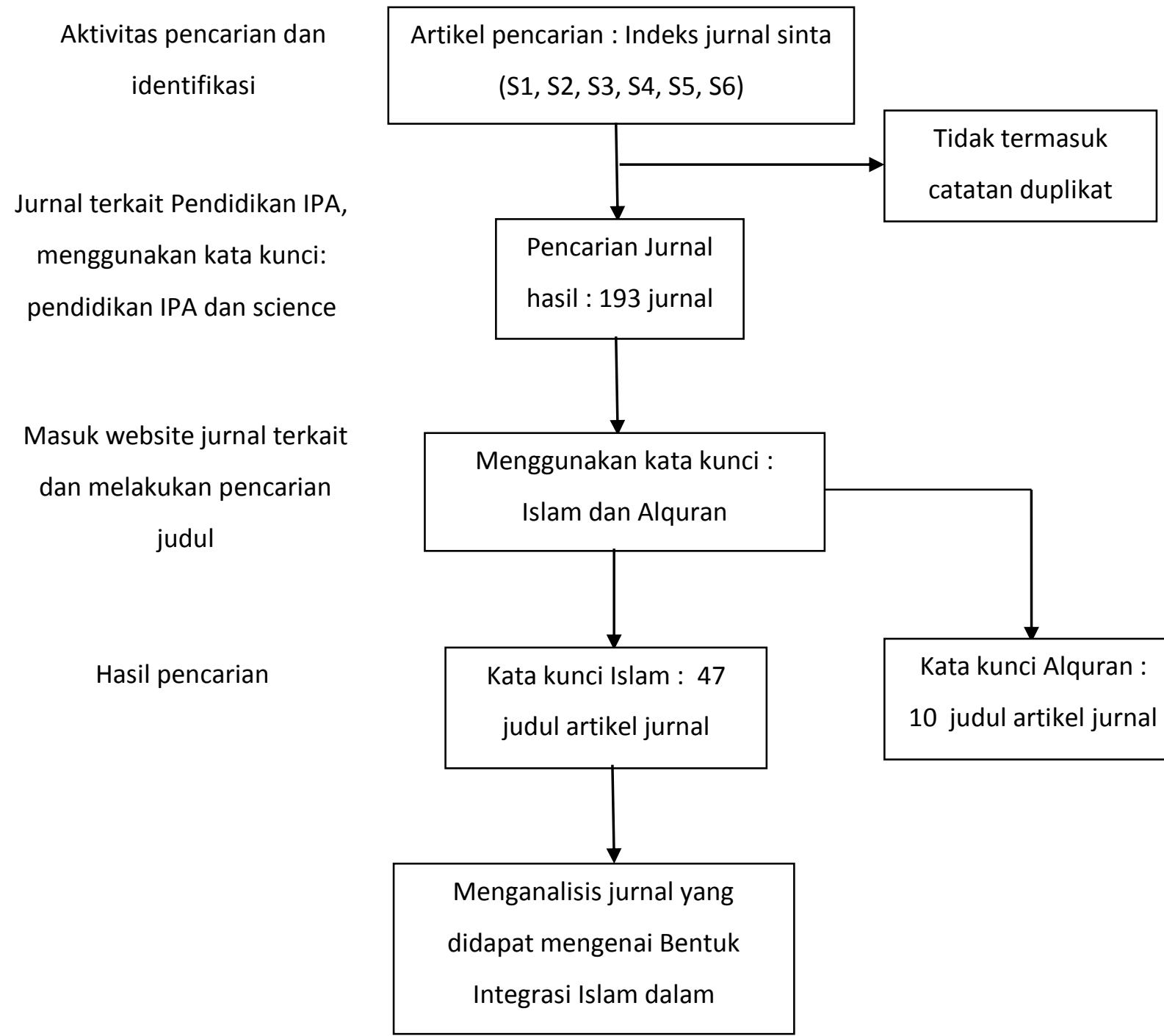

Gambar 1. Diargam prisma dalam metode meta-analisis sistematikal review

\section{HASIL PENELITIAN}

Bentuk integrasi islam di Indonesia sangat bermacam-macam. Untuk mengukur dan mengidentifikasi bentuk integrasi islam dalam pendidikan IPA, berbagai media pembelajaran, penelitian analisis, model pembelajaran, buku, dan modul yang banyak dikembangkan. Berikut merupakan hasil dari penelitian yang dilakukan oleh penulis. 
Tabel 1. Hasil pengumpulan data dari indeks jurnal

\begin{tabular}{|c|c|c|c|c|c|}
\hline \multirow{3}{*}{ No. } & \multirow{3}{*}{$\begin{array}{c}\text { Indeks } \\
\text { Jurnal }\end{array}$} & \multicolumn{4}{|c|}{ Jurnal Pendidikan IPA \& Science } \\
\hline & & \multirow[t]{2}{*}{$\begin{array}{l}\text { Jumlah } \\
\text { Jurnal }\end{array}$} & \multicolumn{2}{|c|}{$\begin{array}{l}\text { Jumlah Artikel } \\
\text { berkaitan dengan } \\
\text { kata }\end{array}$} & \multirow[t]{2}{*}{ Bentuk Integrasi Islam } \\
\hline & & & Islam & Alquran & \\
\hline 1. & Sinta 1 & 17 Jurnal & - & - & - \\
\hline 2. & Sinta 2 & 29 Jurnal & $\begin{array}{l}4 \text { Judul } \\
\text { Artikel }\end{array}$ & - & $\begin{array}{l}\text { Model yang digunakan yakni } \\
\text { menggunakan pengembangan } \\
\text { model procedural, model yang } \\
\text { digunakan bahan ajar dalam } \\
\text { bentuk buku siswa MTs dan } \\
\text { buku guru MTs, flipbook sebagai } \\
\text { media pembelajaran fisika, model } \\
\text { kurikulum. }\end{array}$ \\
\hline 3. & Sinta 3 & 56 Jurnal & $\begin{array}{l}19 \\
\text { Judul } \\
\text { Artikel }\end{array}$ & $\begin{array}{l}4 \text { Judul } \\
\text { Artikel }\end{array}$ & $\begin{array}{l}\text { Model yang digunakan yakni } \\
\text { menggunakan } \\
\text { pembelajaran quantum learning, } \\
\text { RPP pembelajaran biologi pada } \\
\text { kurikulum 2013, modul } \\
\text { pembelajaran } \\
\text { menggunakan } \\
\text { pembelajaran, } \\
\text { pembelajaran metode } \\
\text { pembelajaran kimia dengan } \\
\text { pendekatan saintifik }\end{array}$ \\
\hline 4. & Sinta 4 & 55 jurnal & $\begin{array}{l}13 \text { judul } \\
\text { artikel }\end{array}$ & $\begin{array}{l}4 \text { judul } \\
\text { artikel }\end{array}$ & $\begin{array}{l}\text { Model yang digunakan yakni } \\
\text { dalam bentuk modul tematik, } \\
\text { integrasi Islam dalam bentuk } \\
\text { pembelajaran matematika } \\
\text { ekonomi, berbentuk alquran } \\
\text { hadits \& kepribadian Rasulullah } \\
\text { \& khulafaur rashidin, integrasi } \\
\text { islam dalam bentuk kedudukan } \\
\text { anak perempuan dalam } \\
\text { pembagian hukum waris menurut } \\
\text { islam, bentuk aqidah \& akhlak } \\
\text { dalam ajaran islam, peningkatan } \\
\text { intelijen, perspektif ekonomi dan }\end{array}$ \\
\hline
\end{tabular}




\begin{tabular}{|c|c|c|c|c|c|}
\hline & & & & & $\begin{array}{l}\text { faktor-faktor } \\
\text { mempengaruhi, dalam bentuk } \\
\text { kejujurandan rasa bertanggung } \\
\text { jawab, penggunaan kontrak } \\
\text { dalam instrumen Islamic } \\
\text { hedging, bentuk perpustakaan, } \\
\text { integrasi islam dalam kasus } \\
\text { perkawinan, menggunakan } \\
\text { alquran, integrasi antara sains \& } \\
\text { islam. }\end{array}$ \\
\hline 5. & Sinta 5 & 31 jurnal & $\begin{array}{l}7 \text { judul } \\
\text { artikel }\end{array}$ & $\begin{array}{l}1 \text { judul } \\
\text { artikel }\end{array}$ & $\begin{array}{l}\text { Model yang digunakan yakni } \\
\text { materi pelajaran, sistem layanan } \\
\text { kesehatan, integrasi alquran } \\
\text { dengan teknik inexact string } \\
\text { matching, pancasila, kitab } \\
\text { hukum, pemahaman filosofis, } \\
\text { aplikasi mobile berbasis android. }\end{array}$ \\
\hline 6. & Sinta 6 & 5 jurnal & $\begin{array}{l}4 \text { judul } \\
\text { artikel }\end{array}$ & $\begin{array}{l}1 \text { judul } \\
\text { artikel }\end{array}$ & $\begin{array}{l}\text { Model yang digunakan yakni } \\
\text { program belajar, pelajaran } \\
\text { akademis, pembinaan, aksi } \\
\text { kreativitas, } \\
\text { ekstrakulikuler, analisis masalah, } \\
\text { menggali memahami dan } \\
\text { mendeskripsikan alquran. }\end{array}$ \\
\hline
\end{tabular}

\section{PEMBAHASAN}

Pada bab ini akan membahas dan menganalisis hasil temuan penelitian untuk merekontruksi konsep yang didasarkan pada informasi empiris. Pembahasan pada bagian ini difokuskan pada dua hal yang akan menjadi fokus dari penelitian, yakni : Pertama, Bentuk integrasi Islam dalam Pendidikan. Kedua, Pengembangan nilai Islam dalam Pendidikan IPA.

\section{A. Bentuk integrasi Islam dalam Pendidikan}

Dari tabel diatas menunjukkan bahwa dalam jurnal Sinta 1 sampai Sinta 6 terdapat 193 jurnal yang ditemukan dalam pencarian kata kunci pendidikan IPA dan science. Dari jumlah penemuan jurnal sebanyak 193 didalamnya terdapat artikel yang 
berkaitan dengan agama islam sebanyak 47 artikel dan artikel yang berkaitan dengan Al-Qur'an sebanyak 10 artikel. Selain itu dalam Sinta 1 terdapat 17 jurnal yang penelitiannya tidak berkaitan dengan agama islam dan Al-Qur'an. Sehingga tidak dapat ditemukan bentuk integrasi islam dalam jurnal-jurnal Sinta 1. Untuk memperjelas data berbagai bentuk penerapan integrasi islam dalam Ilmu Pengetahuan Alam dapat dilihat pada diagram bentuk integrasi islam.

\section{Bentuk Integrasi Islam}

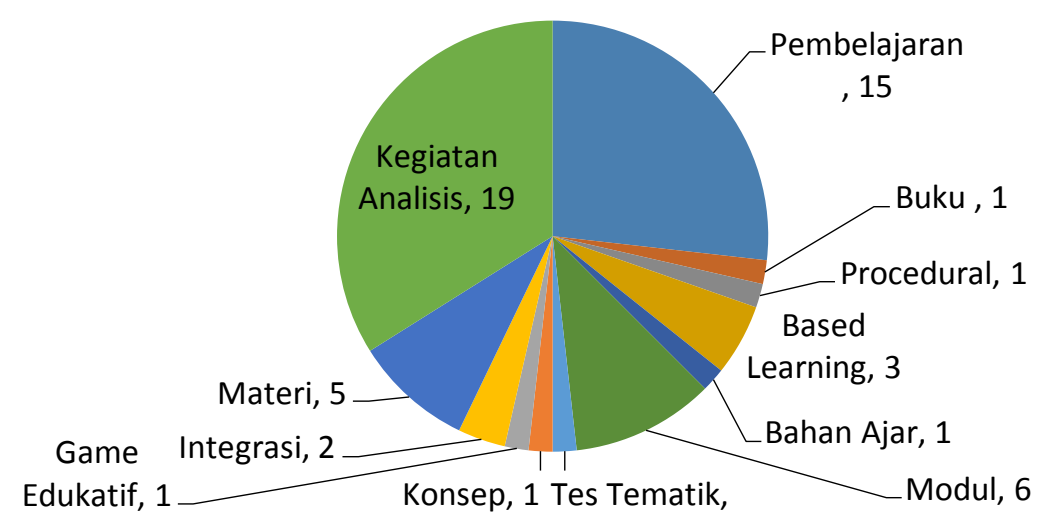

\section{Gambar 2. Diagram bentuk integrasi islam}

Hasil penelitian menunjukkan bahwa bentuk integrasi islam terbanyak melalui kegiatan analisis dan pembelajaran. Kegiatan analisis yang dimaksud adalah kegiatan dari berbagai latar belakang sosial yang berkaitan dengan hukum islam, ekonomi, sosial, kesehatan, perkawinan dan filosifis. Latar belakang tersebut termasuk ke dalam sains humaniora. Bentuk integrasi Islam dalam pembelajaran menunjukkan penerapan Islam pada pelajaran kimia, fisika, matematika ekonomi dan biologi. Dapat dilihat bahwa integrasi Islam pada sains kealaman (natural science) masih sedikit. Begitu pula kajian yang dilakukan oleh Muhammad Munadi (2016), dalam penelitiannya yang berjudul "Integrasi Islam dan Ilmu dalam Praktek di Lembaga Pendidikan”, menyatakan bahwa tidak banyak kajian integrasi Islam dan Ilmu sains natural di beberapa instansi seperti IAIN Surakarta, SMA Trensain Tebu Ireng Jombang, SMA Trensains Sragen di bawah Muhammadiyah, PGMI dan PGMA. Kebanyakan beberapa Instansi masih terfokus pada ilmu humaniora dan sains alam. 
Hal tersebut dapat terjadi sebab jumlah sumber daya yang berlatar belakang sains humaniora dan sosial lebih dominan.(Munadi 2016)

\section{B. Pengembangan Nilai Islam dalam Pendidikan IPA}

Berkaitan dengan suatu pendidikan yang merupakan merupakan proses pendewasaan seseorang baik intelektual, emosional maupun spiritual dan akan sangat berpengaruh pada masa depan peserta didik, negara, bangsa dan agama maka harus dilakukan terprogram, sistematis terpadu dan integral. Hasan Hanafi mengatakan bahwa ajaran dasar Islam yang sesungguhnya adalah tidak mengenal dikotomi, akan tetapi watak dasar Islam adalah menjembatani dua gap tersebut. Isalam adalah religion of nature hal ini dapat diartikan bahwa segala bentuk dikotomi antar agama dan sains harus dihindari.(Maksudin 2015)

Pendekatan integratif-interkonektif adalah usaha untuk menjadikan sebuah keterhubungan antara keilmuan agam dan keilmuan umum. Muara dari pendekatan integratif-interkonektif menjadikan keilmuan melalui proses obyektivikasi. Dengan demikian keilmuan yang hadir dapat dirasakan oleh semua orang baik seseorang dari agama Islam maupun non Islam. Keilmuan yang ada menjadi sesuatu yang natural, tidak sebagai perbuatan keagamaan.(Kuntowijoyo 2005)

Terkait integrasi Islam dalam pembelajaran IPA, pendekatan dalam membahas hubungan Islam, sains dan teknologi yaitu : (1) Menunjukkan bagaimana Islam mendorong, membangkitkan, merangsang dan mengalami penemu sains dan teknologi. (2) Mengulas sumbangan umat Islam bagi perkembangan sains dan teknologi. (3) Membahas secara falsafi Islam, sains dan teknologi. (4) Menentukan apakah ada Islam yang Islami. (5) Menggambarkan bagaimana perkembangan sains dan teknologi dewasa ini, lalu apa yang harus dilakukan?.(Rahmat 1998) Pendekatan tersebut berguna untuk melihat cara dalam hal melakukan pendekatan atau pertemuan dalam Islam dan Sains tersebut.

Pembelajaran IPA di sekolah masih minim dalam penerapan integrasi Islam, baik dalam bentuk model, metode atau pendekatan pembelajaran. Pentingnya integrasi nilai-nilai Islam dalam pendidikan IPA menjadi satu kerangka normatif dalam merumuskan tujuan pendidikan sebagaimana yang diungkapkan Ali dan Luluk 
(2004), bahwa tujuan penanaman nilai-nilai Islam : (1) Mengembangkan wawasan spritual dan pemahaman rasional mengenai Islam dalam konteks kehidupan terutama yang berkaitan dengan ayat-ayat kauniyah (alam). (2) Membekali siswa dengan berbagai kemampuan pengetahuan alam. (3) Mengembangan kemampuan pada diri siswa untuk menghargai dan membenarkan superioritas komparatif khazanah pengetahuan Islam di atas semua khazanah pengetahuan lain. (4) Memperbaiki dorongan emosi melalui pengalaman imajinatif (5) Membantu anak yang sedang tumbuh untuk berpikir secara logis dan membimbing proses pemikirannya dengan berpijak pada konsep-konsep pengetahuan alam yang dituntut.(Luluk Y.R 2004)

Agar memperkuat nilai keislaman dalam pendidikan maka perlu dilakukan pengembangan pembelajaran IPA yang terintegrasi nilai islam. Seperti penelitian yang dilakukan oleh Susilowati (2017), dalam penelitiannya menghasilkan bahan ajar IPA yang terintegrasi nilai Islam. Buku yang dikembangan berjudul Lingkungan (Dalam Perspektif Sains Islam) dapat meningkatkan sikap religi, meningkatkan sikap positif terhadap IPA, dan meningkatkan prestasi belajar IPA.(S.Susilowati 2017)

\section{KESIMPULAN}

Berdasarkan hasil review yang dilakukan terkait dengan bentuk integrasi islam dalam pendidikan IPA di Indonesia, dapat disimpulkan bahwa penerapan integrasi islam dalam pendidikan IPA telah terlaksana dengan cukup banyak dan memiliki berbagai macam bentuk penerapan integrasi Islam. Peneliti menemukan berbagai topik yang berkaitan dengan integrasi islam. Namun, integrasi Islam dalam bentuk pembelajaran IPA di Indonesia masih sedikit dikarenakan jumlah sumber daya yang berlatar belakang sains humaniora dan sosial lebih dominan. Pengembangan nilai Islam dalam pendidikan dapat dilakukan melalui model pengembangan bahan ajar, metode, ataupun pendekatan pembelajaran. 


\section{DAFTAR PUSTAKA}

Departemen Agama RI. 1996. Pola Pembinaan Pendidikan Agama Islam Terpadu. Jakarta: Dirjen Pembinaan Kelembagaan Agama Islam.

Kuntowijoyo. 2005. Islam Sebagai Ilmu. Jakarta: Teraju.

Luluk Y.R, M., Ali. 2004. Paradigma Pendidikan Universal di Era Modern dan Post-Modern; Mencarrai "Visi Baru" atas Realitas Baru" Pendidikan Kita. Yogyakarta: Institut for Religion and Civil Society Development (Ircisod).

Maksudin. 2015. Desain Pengembangan Berpikir Integratif Interkonektif Pendekatan Dialektif. Yogyakarta: Pustaka Pelajar.

Moher, D., Liberati, A., Tetzlaff, J., \& Altman, D. G. 2009. "Preferred Reporting Items for Systemat $\neg$ ic Reviews and Meta-Analyses: The PRISMA Statement. Annals of Internal Medicine." 4(151):264-69.

Munadi, Muhammad. 2016. "Integrasi Islam dan Ilmu Dalam Praktek di Lembaga Pendidikan." Institus Agama Islam Negeri Surakarta.

Rahmat, Jalaluddin. 1998. Islam Alternative. Bandung: Mizan.

S.Susilowati. 2017. "Pengembangan Bahan Ajar IPA Terintegrasi Nilai Islam untuk Meningkatkan Hasil Belajar IPA.” Jurnal Inovasi Pendidikan IPA. 1(3):78-77.

Sumantri, E. 2007. Pendidikan Nilai Kontemporer. Bandung: Program Studi PU UPI.

UU RI No. 20 Tahun 2003. t.t. Tentang Sistem Pendidikan Nasional. Jakarta: Sinar Grafika. 